\title{
IMPLEMENTASI MANAJEMEN PENINGKATAN MUTU MADRASAH
}

\author{
Nurul Yaqien ${ }^{1}$
}

\begin{abstract}
Discussing about the implementation of madrasa quality increasement management is inseparable from the concept of management, roles and responsibility of management, the concept of quality, and how to implement madrasa quality increasement management itself. The effort of increasing quality of madrasa is basically conducted to face the competitive educational world, especially to face the issue of ASEAN community which starts from 2015. Furthermore, the big challenge for madrasa is how should madrasa prepare themself in increasing students' competencies and all aspect related to instructional process. Therefore, the concept related to management, roles and responsibility of management, the concept of quality, and how to implement madrasa quality increasement management itself will be discussed below.
\end{abstract}

Keywords: Management, Quality, Madrasa.

\section{A. Pendahuluan}

Kata "mutu" merupakan idaman bagi setiap lembaga/instansi, tidak terkecuali lembaga pendidikan Islam. Madrasah merupakan salah satu lembaga pendidikan yang berciri khas Islam. Madrasah memiliki kesempatan yang sama dengan lembaga pendidikan umum untuk dalam peningkatan mutu. Mutu pembelajaran yang baik akan menghasilkan output ataupun outcome yang baik pula. Banyak teori yang menyatakan bahwa proses pembelajaran yang baik pada hakikatnya merupakan cerminan dari hasil yang akan diperoleh. Sebaliknya bahwa proses pembelajaran yang kurang baik atau kurang bermutu akan menghasilkan keluaran yang kurang baik pula.

Dalam catatan sejarah madrasah sudah banyak dibahas mengenai kondisi madrasah zaman dahulu yang nasibnya termarginalkan. Berbeda dengan masa lalu madrasah saat ini sudah mulai menata diri untuk menjadi yang lebih baik. Walaupun sudah mulai menata

1 Dosen Fakultas Ilmu Tarbiyah \& Keguruan UIN Maulana Malik Ibrahim Malang 
diri untuk menjadi lebih baik akan tetapi masih banyak kendalakendala yang dihadapi madarasah terkait manajemen madrasah. Kondisi madrasah semacam ini menjadikan madrasah harus bekerja keras terutama dalam memasuki abad 21 dengan berbagai, tantangan dunia global semakin terbuka. Adanya ASEAN Community yang telah dimulai pada tahun 2015 ini menjadikan dunia pendidikan terutama madrasah harus meningkatkan kompetensinya untuk lebih baik lagi.

Madrasah merupakan salah satu lembaga pendidikan Islam yang juga harus meningkatkan kompetensi peserta didiknya dalam rangka menghadapi ASEAN Community. Salah satu upaya yang harus dilakukan oleh madrasah dalam menghadapi perkembangan zaman ini adalah peningkatan mutu pelayanan pendidikan baik dengan mengimplementasikan manajemen peningkatan mutu dalam segala hal seperti: proses pembelajaran, fasilitas yang diberikan, kemudahan berkomunikasi, guru yang kompeten, dan lain sebagainya yang berkaitan dengan peningkatan mutu peserta didik.

Membahas masalah implementasi manajemen peningkatan mutu madrasah pasti tidak lepas dari pembahasan terkait dengan konsep manajemen, tugas dan tanggung jawab pengelolaan manajemen, konsep mutu, dan bagaimana implementasi manajemen peningkatan mutu itu sendiri. Konsep manajemen pada hakikatnya membahas bagaimana sesungguhnya madrasah tersebut melakukan fungsi-fungsi manajemen terkait dengan mengelola mutu, seperti proses rektutmen peserta didik, proses pembelajaran, fasilitas baik fisik maupun non fisik, evaluasi dan lain sebagainya dalam rangka mencapai output atau outcome yang bermutu.

\section{B. Pembahasan}

\section{Konsep Manajemen}

Kata manajemen menurut Mochtar Effendy (1986 : 6), berasal dari bahasa Inggris, yakni dari kata kerja to manage yang bersinonim dengan kata to hand yang berarti mengurus, to control memeriksa dan to guide yang berarti memimpin. Jadi, apabila dilihat dari arti etimologi, manajemen berarti pengurusan, pengendalian, memimpin atau membimbing. 
Sedangkan pengertian manajemen secara terminologi sebagaimana dikemukakan oleh Fridreck Taylor adalah : Management, the art of management is defined as knowing exactly what you want to do, and then seing that they do tersebut in the bestand cheapest way. Manajemen adalah seni yang ditentukan untuk mengetahui dengan sungguhsungguh apa yang ingin kamu lakukan, dan mangawasi bahwa mereka mengerjakan sesuatu dengan sebaik-baiknya dan dengan cara yang semudah-mudahnya (Taylor:1974:2).

Manajemen sering diartikan sebagai ilmu, kiat, dan profesi. Dikatakan sebagai ilmu oleh Luther Gulick karena manajemen dipandang sebagai suatu bidang pengetahuan yang secara sistematik berusaha memahami mengapa dan bagaimana orang bekerjasama. Dikatakan sebagai kiatoleh Follet karena manajemen mencapai sasaran melalui cara-cara dengan mengatur orang lain dalam menjalankan tugas. Dipandang sebagai profesi karena manajemen dilandasi oleh keahlian khusus untuk mencapai suatu prestasi manajer, dan para profesional dituntun oleh suatu kode etik (Fattah, 2009:1).

Malayu S. P. Hasibuan mengartikan manajemen adalah ilmu dan seni mengatur proses pemanfaatan sumber daya manusia dan sumbersumber lainnya secara efektif dan efisien untuk mencapai suatu tujuan tertentu (Hasibuan, 2012: 1-2). Lebih lanjut Richard L. Daft menjelaskan bahwa manajemen (management) adalah pencapaian tujuan organisasi dengan cara yang efektif dan efisien melalui perencanaan, pengorganisasian, pengarahan, dan pengendalian sumber daya organisasi (Daft, 2008:6).

Beberapa definisi tersebut di atas, maka dapat diketahui bahwa manajemen merupakan suatu ilmu dan seni yang dimiliki oleh manusia dalam upaya memanfaatkan sumber daya manusia (SDM) dan sumber daya yang lain dalam kegiatan perencanaan, pengorganisasian, pelaksanaan dan pengawasan, yang dilakukan secara efektif dan efisien dengan melibatkan seluruh anggota secara efektif dan efisien untuk mencapai tujuan yang telah ditetapkan sebelumnya.

Dalam konsep Islam, manajemen lebih diartikan sebagai tindakan mengatur segala sesuatu dengan penuh tanggungjawab sesuai dengan tugas yang telah dibebankan untuk mencapai tujuan yang telah ditetapkan. Hal ini sesuai dengan isyarat yang ditunjukkan dalam Al-Qur'an berikut: 


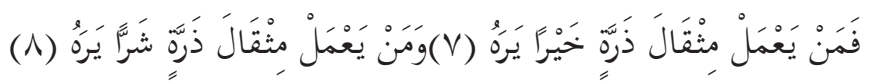

Artinya: "Barangsiapa yang mengerjakan kebaikan seberat dzarrahpun, niscaya Dia akan melihat (balasan)nya.dan Barangsiapa yang mengerjakan kejahatan sebesar dzarrahpun, niscaya Dia akan melihat (balasan)nya pula.(QS. Al- Zalzalah; 99: 7-8)

$$
\text { إِ..... }
$$

Artinya: ".....Dan janganlah kamu mengikuti apa yang kamu tidak mempunyai pengetahuan tentangnya. Sesungguhnya pendengaran, penglihatan dan hati, semuanya itu akan diminta pertanggungan jawabnya." (QS. Al Israa; 17: 36)

Kedua ayat tersebut menunjukkan bahwa setiap tindakan manusia baik kecil maupun besar akan mempunyai konsekwensi dan harus dipertanggungjawabkan di hadapan penguasa alam ini. Dalam dunia manajemen setiap tindakan juga akan dipertanggung jawabkan kepada atasan atau pimpinan, karena tindakan tersebut membawa konsekwensi baik dan buruknya kepada lembaga. Dalam konteks ini, manajemen sangat diperlukan guna meminimalisir konsekwensi negatif yang akan muncul dari setiap tindakan yang akan diperbuat. Dalam rangka peningkatan mutu madrasah konsep manajemen ini sesuai dengan ajaran Islam yang menginginkan setiap pekerjaan harus dilakukan dengan sungguh-sungguh untuk menghasilkan sesuatu yang memuaskan. Dalam konteks ini sesuatu yang berharga tersebut adalah lulusan dengan memiliki kompetensi yang tinggi.

\section{Tugas dan Tanggung Jawab Pengelolaan Manajemen}

Pada prinsipnya pengertian manajemen tersebut di atas mempunyai beberapa karakteristik sebagai berikut: (1) ada tujuan yang ingin dicapai; (2) sebagai perpaduan ilmu dan seni; (3) merupakan proses yang sistematis, terkoordinasi, koperatif, dan terintegrasi dalam memanfaatkan unsur-unsurnya; (4) ada dua orang atau lebih yang bekerjasama dalam suatu organisasi; (5) didasarkan pada pembagian kerja, tugas dan tanggung jawab; (6) mencakup beberapa fungsi; (7) merupakan alat untuk mencapai tujuan (Hasibuan, 2001 : 3). 
Manajemen merupakan suatu proses pengelolaan sumber daya yang ada mempunyai empat fungsi yaitu perencanaan, pengorganisasian, penggerakan, dan pengawasan. Hal ini sesuai dengan pendapat George R. Terry dalam Sutopo yang menyatakan bahwa fungsi manajemen mencakup kegiatan-kegiatan:

a. Perencanaan (planning),: Budgetting, Programming, Decision Making, Forecasting;

b. Pengorganisasian (organizing): Structuring, Assembling Resources, Staffing

c. Penggerakan (directing): Coordinating, Directing, Commanding, Motivating, Leading, Motivating,

d. Pengawasan (controlling): Monitoring, Evaluating, Reporting yang dilakukan untuk mencapai sasaran yang telah ditetapkan melalui pemanfaatan sumber daya manusia dan sumberdaya lainnya (Sutopo, 1999: 14).

Proses kegiatan manajemen dalam dunia pendidikan merupakan suatu sistem yang terdiri dari sub-sub sistem yang saling berkaitan satu dengan yang lain. Kegiatan tersebut merupakan satu kesatuan yang saling mempengaruhi. Perencanaan, pengorganisasian, penggerakan dan pengawasan tidak dapat dipisahkan satu dengan yang lain meskipun pelaksanaannya dikerjakan oleh unit-unit kerja yang berbeda. Apabila keterpaduan proses kegiatan tersebut dapat terlaksana dengan baik, maka keterpaduan proses kegiatan tersebut menjadi suatu siklus proses kegiatan yang dapat menunjang perkembangan dan peningkatan kualitas kerja (Sutopo, 2001:5).

Upaya pencapaian tujuan pendidikan harus direncanakan dengan memperhitungkan sumberdaya, situasi, dan kondisi yang ada dalam rangka mencapai tujuan yang efektif. Semua sumberdaya yang terkait dan pelaksanaan kegiatan tersebut perlu dikoordinasikan secara terpadu agar tercapai suatu kerjasama yang harmonis dalam mencapai tujuan tersebut. Keterpaduan kerja organisasi memerlukan pengarahan, dorongan, koordinasi, dan kepemimpinan efektif. Pelakasanan semua kegiatan tersebut harus dikendalikan, dimonitor dan dievaluasi kefektifan dan keefisiennya. Hasilnya merupakan feedback yang sangat berguna untuk menyempurnakan dan meningkatkan perencanaan, pengorganisasian, dan pelaksaanaan kegiatan berikutnya (Sutopo, 2001:5). 
Nurul Yaqien - ImplemEntasi Manajemen Peningkatan Mutu ...

Secara visual siklus proses kegiatan manajemen dapat digambarkan sebagai berikut:

\section{Gambar. 2.1 Siklus Manajemen}

Siklus Kegiatan Manajemen

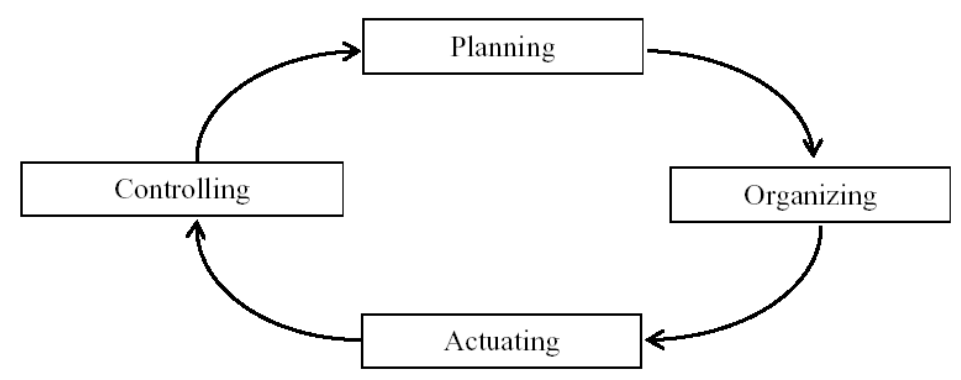

Tugas dan tanggung jawab kepala sekolah/madrasah adalah merencanakan, mengorganisasikan, mengarahkan, mengkoordinasikan, mengawasi dan mengevaluasi seluruh kegiatan sekolah, yang meliputi bidang proses belajar mengajar, peningkatan dan pengembangan kinerja guru, administrasi kantor, administrasi siswa, administrasi pegawai, administrasi perlengkapan, administrasi keuangan, administrasi perpustakaan, dan administrasi hubungan masyarakat (Burhanuddin, 1994:29).

Dalam rangka mencapai tujuan organisasi, kepala sekolah / madrasah pada dasarnya mempunyai tugas dan tanggung jawab untuk melakukan perencanaan, pengorganisasian, penggerakan, dan pengawasan terhadap seluruh sumberdaya yang ada dan kegiatankegiatan yang dilakukan di madrasahnya.

Adapun penjelasan mengenai unsur atau fungsi/kegiatan dari manajemen adalah sebagai berikut:

\section{a. Perencanaan (planning)}

Dalam upaya mengimplementasikan peningkatan mutu madarah fungsi fungsi manajemen harus dilaksanakan diantaranya yang pertama adalah fungsi perencanaan. Perencanaan merupakan kegiatan pertama dalam proses manajemen yang akan membahas tentang apa yang akan dikerjakan dalam rangka mencapai tujuan yang diharapkan perlu persiapan dan dipikirkan secara intensif. 
Menurut Arikunto (2001:9), perencanaan adalah suatu proses mempersiapkan serangkaian keputusan untuk mengambil tindakan dimasa yang akan datang yang diarahkan kepada tercapainya tujuan-tujuan dengan sarana yang optimal.

Sondang P. Siagian (2002:103) menyatakan bahwa dalam perencanaan kegiatan dirumuskan dan ditetapkan seluruh aktivitas lembaga yang menyangkut apa yang harus dikerjakan, mengapa dikerjakan, kapan akan dikerjakan, siapa yang mengerjakan dan bagaimana hal tersebut dikerjakan. Kegiatan yang dilakukan dalam perencanaan dapat meliputi penentuan tujuan, penegakkan strategi, dan pengembangan rencana untuk mengkoordinasikan kegiatan. Dengan demikian dapat dipahami bahwa perencanaan itu meliputi kegiatan yang diarahkan untuk mencapai suatu tujuan dengan terlebih dahulu menentukan siapa yang akan terlibat, cara atau metode apa yang akan digunakan, dan waktu pelaksanaannya kapan. Hal itu penting untuk dilakukan untuk menghindari ketidakmaksimalan dalam pencapaian tujuan karena suatu usaha tanpa direncanakan sukar diharapkan daya guna dan hasil gunannya.

Perencanaan dapat sebagai suatu proses pikir yang sistematis dalam menetapkan apa, bagaimana, dan kapan kegiatankegiatan dilaksanakan dalam rangka mencapai tujuan yang telah ditetapkan secara efektif dan efisien. Menurut Soetopo (2001:7), secara sistematis proses berpikir tersebut bertahap dan dapat digambarkan sebagai berikut:

a) Tahap pertama: tujuan pendidikan yang akan dicapai harus sudah tergambar secara jelas atau secara operasional.

b) Tahap kedua: situasi dan kondisi harus dipelajari yang terdiri dari sumber daya yang dapat dimanfaatkan, kendala dan hambatan yang mungkin timbul, upaya yang dapat dilaksanakan untuk menanggulanginya. Analisis seperti itu dapat dilaksanakan apabila data dan informasi itu dapat dipercaya dan kemampuan menganalisis ikut menentukan kualitas rencana yang akan disusun.

c) Tahap ketiga: berdasarkan hasil analisis tersebut perencanaan harus dapat menemukan berbagai alternatif cara atau metode atau strategi yang dapat dipergunakan untuk mencapai tujuan yang diharapkan. 
d) Tahap keempat: perencanaan harus dapat menentukan alternatif yang terbaik dari berbagai alternatif yang ada. Bagaimanapun hasil analisisnya keputusan harus diambil, cara, metode, atau strategi mana yang berdaya guna dan berhasil guna dalam proses pencapaian tujuan.

e) Tahap kelima: penyusunan rencana yang meliputi: tujuan yang akan dicapai, metode atau cara atau strategi yang digunakan, sarana dan prasarana yang diperlukan, waktu pelaksanaannya, siapa yang melaksanakan, dan alat untuk mengevaluasi hasil kegiatannya.

Secara singkat dapat dikatakan bahwa proses perencanaan pendidikan meliputi kegiatan-kegiatan perumusan dan penetapan tujuan pendidikan, analisis situasi dan kondisi, perumusan masalah, identifikasi hambatan, eksplorasi alternatif pemecahan masalah dan kegiatan pencapaian tujuan, dan terakhir menetapkan kriteria keberhasilan sebagai ukuran tercapainya tujuan.

Soetopo (2001:8-9), menjabarkan bahwa dalam pencapaian tujuan suatu perencanaan perlu memperhatikan azas-azas berikut:

a) Azas Komprehensif (menyeluruh) yaitu pemikiran yang berwawasan menyeluruh dalam menganalisis situasi, kondisi dan sumber daya yang ada, kemudian memilih metode atau cara yang akan dipakai, menentukan sarana, dan waktu.

b) Azas Integratif (keterpaduan) yaitu suatu pemikiran atau wawasan yang memperhatikan pengaruh atau keterikatan faktor-faktor lain non pendidikan

c) Azaz Kontinyuitas (kesinambungan) yaitu kesinambungan rencana yang dibuat dengan tingkat situasi dan kondisi yang sudah dilaksanakan.

d) Azas Praktis atau Visibilitas yaitu suatu pemikiran yang mengutamakan segi pragmatisnya suatu rencana.

e) Azas fleksibel (lentur) yaitu menyusun suatu rencana yang mudah disesuaikan dengan perubahan atau perkembangan situasi dan kondisi yang ada.

f) Azas berhasil guna dan berdaya guna (efektif dan 
efisien) yaitu suatu rencana yang mengacu secara tepat kepada tercapainya tujuan yang diharapkan, dan dapat memanfaatkan sumber-sumber daya secara minimal, tidak boros.

Perencanaan memiliki tujuan dan manfaatdalamilmu manajemen. Tujuan perencanaan meliputi: (1) Standar pengawasan yaitu mencocokkan pelaksanaan dengan perencanaanya, (2) Mengetahui kapan pelaksanaan dan selesainya suatu pekerjaan, (3) Mengetahui siapa saja yang terlibat (struktur organisasinya) baik kualifikasinya maupun kuantitasnya, (4) Mendapatkan kegiatan yang sistematis termasuk biaya dan kualitas pekerjaan, (5) Meminimalkan kegiatan-kegiatan yang tidak produktif dan menghemat tenaga, biaya dan waktu, (6) Memberikan gambaran yang menyeluruh mengenai Kegiatan pekerjaan, (7) Menyerasikan dan memadukan beberapa sub-kegiatan, (8) Mendeteksi hambatan kesulitan yang bakal ditemui, dan (9) Mengarahkan pada pencapaian tujuan, (Usman, 2010: 60).

Adapun manfaat perencanaan adalah: (1) Standar pelaksanaan dan pengawasan, (2) Pemilahan berbagai alternatif terbaik, (3) Penyusunan skala prioritas, baik sasaran maupun kegiatan, (4) Menghemat pemanfaatan organisasi, (5) Membantu manajer menyesuaikan diri dengan perubahan lingkungan, (6) Alat memudahkan dalam berkoordinasi dengan pihak terrkait, dan (7) Alat meminimalkan pekerjaan yang tidak pasti, (Usman, 2010: $60)$.

Untukmenghasilkan perencanaanyang baik perlumemperhatikan asas-asas berikut yaitu: (1) Asas pencapaian tujuan, (2) Asas dukungan data yang akurat, (3) Asas menyeluruh (komprehensif dan integrated), dan (4) Asas praktis (Mulyono, 2008:26-27). Dalam menyusun perencanaan, manajer atau perencana perlu memperhatikan dan mempertimbangkan asas-asas tersebut agar perencanaan yang dibuat dapat dilaksanakan dan dapat mencapai tujuan yang telah ditetapkan.

Adapun jenis dan macam perencanaan dapat diklasifikasikan dari berbagai sudut tinjauan. Bila ditinjau dari sudut waktu pelaksanaan suatu rencana dapat diklasifikasikan sebagai berikut 
a) Rencana jangka panjang :10-25 tahun

b) Rencana jangka menengah : 5 - 9 tahun

c) Rencana jangka pendek :1-4 tahun

Bila ditinjau dari segi telaahnya (pemikirannya) maka jenis perencanaan diklasifikasikan menjadi:

a) Perencanaan strategik (kebijaksanaan)

b) Perencanaan managerial (pengarahan pelaksana)

c) Perencanaan operasional (pelaksanaan teknis)

Kepala madrasah sebagai top management di sekolah mempunyai tugas untuk membuat perencanaan, baik dalam bidang program pembelajaran dan kurikulum, guru dan kepegawaian, kesiswaan, keuangan maupun perlengkapan (Purwanto, 1998:107). Dalam proses perencanaan terhadap program pendidikan yang akan dilaksanakan, khususnya dalam lembaga pendidikan Islam, maka prinsip perencanaan harus mencerminkan terhadap nilainilai yang bersumberkan pada Al-Qur'an dan Al-Hadits. Dalam hal membuat perencanaan prinsip prinsip tersebut diantaranya; dalam surat al-Hajj ayat 77 yang berbunyi :

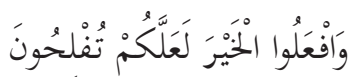

Artinya: ......Dan berbuatlah kebajikan supaya kamu mendapatkan keberuntungan (Q.S. Al-Hajj: 77), (Hatta, 2009:341).

Selain ayat tersebut, terdapat pula ayat yang menganjurkan kepada para manajer dalam melakukan perencanaan untuk menentukan sikap adil dan bijaksana. Yaitu dalam QS An Nahal ayat 90 :

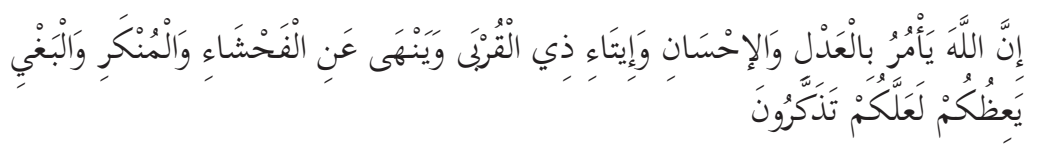

Artinya: Sesungguhnya Allah menyuruh kamu berlaku adil dan berbuat kebajikan atau kebaikan, memberi kepada kaum kerabat dan Allah melarang perbuatan yang keji, mungkar dan permusuhan. Dia memberi pelajaran kepadamu agar kamu dapat mengambil pelajaran (An-Nahl: 90), (Hatta, 2009:277). 
Kedua ayat tersebut merupakan suatu hal yang sangat prinsipil dalam proses perencanaan pendidikan terutama di madrasah, agar supaya tujuan yang ingin dicapai dapat tercapai dengan sempurna. Dengan adanya prinsip keadilan, berbuat kebajikan, dan menjahui perbuatan keji, mungkar dan permusuhan akan menjadikan perencanaan dalam rangka peningkatan mutu madrasah yang telah disusun akan dapat dijalankan dengan baik. Di samping itu pula, intisari ayat tersebut merupakan suatu "pembeda" antara manajemen secara umum dengan manajemen dalam perspektif Islam yang sarat dengan nilai.

b. Pengorganisasian (organizing)

Langkah kedua setelah perencanaan dalam upaya peningkatan mutu madarasah adalah pengorganisasian. Pengorganisasian padasesungguhnyaadalah proseskerjasama sekelompokmanusia yang meliputi berbagai jenis kegiatan yang mengacu kepada tercapainya tujuan yang sama. Supaya kegiatan-kegiatan tersebut terpadu, maka kegiatan-kegiatan itu perlu diorganisasikan yang baik. Jadi pada hakekatnya pengorganisasian mencakup menstrukturkan bagian-bagian, membagi-bagi fungsi, tugas, wewenang, tanggung jawab, dan menentukan mekanisme kerja.

Mengorganisasikan adalah proses mengatur, mengalokasikan, dan mendistribusikan pekerjaan, wewenang dan sumber daya diantara anggota organisasi untuk mencapai tujuan organisasi. (Tim Dosen UPI, 2011:94). Menurut George R. Terry yang dikutip Mulyono, pengorganisasian adalah menyusun hubungan perilaku yang efektif antar personalia, sehingga mereka dapat bekerjasama secara efisien dan memperoleh keputusan pribadi dalam melaksanakan tugas-tugas dalam situasi lingkungan yang ada guna mencapai tujuan dan sasaran tertentu (Mulyono 2008: 27).

Sedangkan pengorganisasian menurut Handoko dalam Husaini Usman ialah: (1) penentuan sumber daya dan kegiatan yang dibutuhkan untuk mencapai tujuan organisasi, (2) proses perancangan dan pengembangan suatu organisasi yang akan dapat membawa hal-hal tersebut ke arah tujuan, (3) penugasan tanggungjawab tertentu, (4) pendelegasian wewenang yang 
diperlukan kepada individu-individu untuk melaksanakan tugas-tugasnya, (Usman, 2010: 141).

Menurut Robbins, bahwa kegiatan yang dilakukan dalam pengorganisasian dapat mencakup (1) menetapkan tugas yang harus dikerjakan; (2) siapa yang mengerjakan; (3) bagaimana tugas itu dikelompokkan; (4) siapa melapor ke siapa; (5) di mana keputusan itu harus diambil (Robbins, 2003: 5).

Beberapa definisi tersebut dapat disimpulkan bahwa pengorganisasian itu adalah mengatur dan mengalokasikan semua sumber daya dan wewenang kepada orang-orang yang dianggap berkompeten untuk mempermudah atau mengfektifkan pencapaian tujuan suatu organisasi. Dalam bahasan ini, tujuan yang ingin dicapai adalah peningkatan mutu madrasah.

Dalam ajaran Islam, pengorganisasian sangat penting untuk dilaksanakan dalam suatu organsasi karena apabila suatu pekerjaan diserahkan kepada yang bukan ahlinya akan menyebabkan kegagalan dalam mencapai tujuan yang telah ditetapkan. Hal itu dapat dipahami dari hadits Nabi SAW:

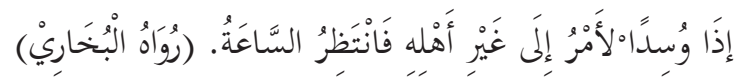

"Apabila suatu perkara diserahkan kepada yang bukan ahlinya maka tunggulah kehancurannya". (HR. Bukhari), (Abdillah, 1992:26).

Wujud dari pelaksanaan organizing ini adalah tampaknya kesatuan yang utuh, kekompakan, kesetiakawanan dan terciptanya mekanisme yang sehat, sehingga kegiatan lancar, stabil dan mudah mencapai tujuan yang ditetapkan, (Thantowi, 1983:71). Proses organizing yang menekankan pentingnnya tercipta kesatuan dalam segala tindakan, dalam hal ini al-Qur'an telah menyebutkan betapa pentingnya tindakan kesatuan yang utuh, murni dan bulat dalam suatu organisasi. Firman Allah dalam surat Ali Imran 103:

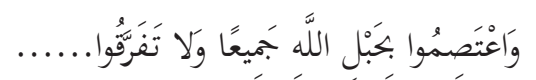

Artinya : Dan berpegang teguhlah kamu semua kepada tali Allah (agama Allah), dan janganlah kamu bercerai berai..... (Q.S. Ali Imran: 103). 
Selanjutnya al-Qur'an memberikan petunjuk agar dalam suatu wadah, tempat, persaudaraan, ikatan, organisasi, kelompok, janganlah timbul pertentangan, perselisihan, percekcokan yang mengakibatkan hancurnya kesatuan, runtuhnya mekanisme kepemimpinan yang telah dibina. Firman Allah dalam surat AlAnfal ayat 46:

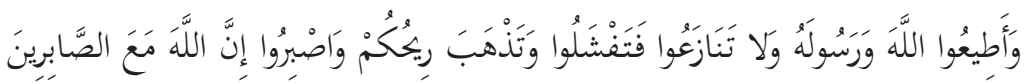

Artinya: Dan taatilah Allah dan RasulNya, jangalah kamu berbantah-bantahan yang menyebabkan kamu menjadi gentar, hilang kekuatanmu, dan bersabarlah, sesungguhnya Allah beserta orang-orang yang sabar. (Q.S. Al-Anfal: 46).

Kedua ayat tersebut di atas menunjukkan bahwa dalam pengorganisasian hendaklah dilandasi oleh sikap persaudaraan dan menghindari adanya perselisihan, percekcokan yang akan mengakibatkan proses kerjasama sekelompok terganggu. Terganggunya proses kerjasama ini akan mengakibatkan terganggunya upaya peningkatan mutu madrasah terkait dengan berbagai program-programnya.

c. Penggerakan (actuating)

Langkah ketiga setelah pengorganisasian dalam upaya peningkatanmutumadarasahadalah penggerakan.Penggerakkan itu dimaksudkan agar tugas, fungsi, tanggungjawab, dan wewenang yang telah diorganisasikan berjalan sesuai dengan kebijaksanaan dan rencana yang telah ditetapkan dalam rangka mencapai tujuan secara efektif dan efisien. Menurut Abdurrahman sebagaimana yang dikemukakan oleh Soetopo bahwa penggerakan merupakan kegiatan manajemen untuk membuat orang-orang mau dan dapat bekerja sesuai dengan fungsi dan tugasnya, (Sutopo, 2001:12). Menggerakkan orangorang bukanlah suatu pekerjaan yang mudah. Untuk itu diperlukan kemampuan atau seni menggerakkan orang lain yang disebut kepemimpinan (leadership).

Bimbingan atau pengarahan menurut Hadari Nawawi (1983:74) adalah memelihara, menjaga dan memajukan organisasi melalui setiap personal, baik secara struktural maupun fungsional, agar 
setiap kegiatannya tidak terlepas dari usaha mencapai tujuan. Masalah penggerakan ini pada dasarnya berkaitan erat dengan unsur manusia sehingga keberhasilannya juga ditentukan oleh kemampuan kepala sekolah/madrasah dalam berhubungan dengan para guru dan karyawannya. Oleh sebab itu, diperlukan kemampuan kepala sekolah/madrasah dalam berkomunikasi, daya kreasi serta inisiatif yang tinggi dan mampu mendorong semangat dari para guru/karyawannya. (Soewadji, 1994:4).

Untuk dapat menggerakkan guru agar mempunyai semangat dan gairah kerja yang tinggi dalam upaya peningkatan mutu madrasah, maka perlu memperhatikan beberapa prinsip berikut:

1. Memperlakukan para pegawai (guru) dengan sebaikbaiknya;

2. Mendorong pertumbuhan dan pengembangan bakat dan kemampuan para pegawai tanpa menekan daya kreasinya;

3. Menanamkan semangat para pegawai agar mau terus berusaha meningkatkan bakat dan kemampuannya;

4. Menghargai setiap karya yang baik dan sempurna yang dihasilkan para pegawai;

5. Mengusahakan adanya keadilan dan bersikap bijaksana kepada setiap pegawai tanpa pilih kasih.;

6. Memberikan kesempatan yang tepat bagi pengembangan pegawainya, baik kesempatan belajar maupun biaya yang cukup untuk tujuan tersebut;

7. Memberikan motivasi untuk dapat mengembangkan potensi yang dimiliki para pegawai melalui ide, gagasan dan hasil karyanya, (Nunung, 1994:56).

Al-Qur'an dalam hal ini telah memberikan pedoman dasar terhadap proses pembimbingan, pengarahan ataupun memberikan peringatan dalam bentuk actuating ini. Allah berfirman dalam Surat al-Kahfi Ayat 2:

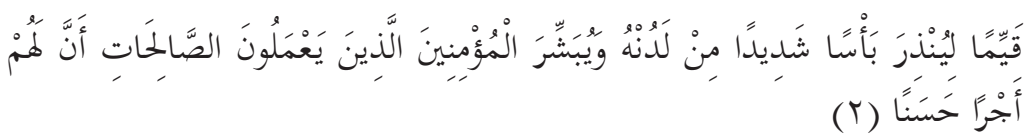


Artinya : Sebagai bimbingan yang lurus, untuk memperingatkan akan siksaan yang sangat pedih dari sisi Allah dan memberi berita gembira kepada orang-orang yang beriman yang mengerjakan amal sholeh, bahwa mereka akan mendapat pahala yang baik. (Q.S. Al-Kahfi: 2).

Ayat tersebut memberikan gambaran bahwa dalam pelaksanaannya nanti diharuskan setiap orang untuk menjalankan rencana program peningkatan mutu madrasah dengan benar. Melaksanakan rencana dengan benar akan membawa dampak pada perolehan pahala dan surga. Sehingga faktor membimbing dan memberikan peringatan sebagai hal penunjang demi suksesnya rencana sangat penting, sebab jika hal itu diabaikan akan memberikan pengaruh yang kurang baik terhadap kelangsungan program madrasah.

d. Pengawasan/evaluasi (controlling and evaluating)

Langkah keempat setelah penggerakan dalam upaya peningkatan mutu madarasah adalah pengawasan. Istilah pengawasan dapat mengandung arti beragam, yaitu dapat berarti inspeksi, kontrol dan evaluasi dalam proses manajemen. Pengawasan pada hakekatnya adalah suatu aktivitas dalam usaha mengendalikan, menilai dan mengembangkan kegiatan organisasi agar sesuai dengan rencana dan tujuan yang telah ditetapkan sebelumnya, (Nunung, 1994:76). Pengawasan merupakan tindakan atau proses kegiatan untuk mengendalikan pelaksanaan. Kesalahan, kegagalan, dan penyimpangan yang terjadi di lapangan perlu diperbaiki dan dicegahjangan sampai terulang kembalikesalahankesalahan tersebut, dan juga menjaga agar pelaksanaan tidak berbeda dengan rencana yang telah ditetapkan.

M. Manullang sebagaimana yang dikutip Soetopo (2001:13) mengartikan pengawasan sebagai proses untuk menetapkan pekerjaan apa yang sudah dilaksanakan, menilainya dan mengoreksi bila perlu, dengan maksud supaya pelaksanaan pekerjaan sesuai dengan rencana semula. Dan Soetopo juga mengutip pendapat Mondy yang mengartikan "controlling is the process of comparing actual performance with standards and taking any necessary corrective action". Pengawasan adalah proses membandingkan untuk kerja aktual dengan standard yang 
telah ditetapkan sebelumnya dan melakukan perbaikan yang diperlukan.

Pangawasan dan evaluasi dapat diartikan sebagai salah satu kegiatan untuk mengetahui realisasi perilaku personel dalam organisasi pendidikan dan apakah tingkat pencapaian tujuan pendidikan sesuai dengan yang dikehendaki, kemudian apakah perlu diadakan perbaikan. Pengawasan dilakukan untuk mengumpulkan data tentang penyelenggaraan kerja sama antara guru, kepala sekolah, konselor, supervisor, dan petugas sekolah lainnya dalam institusi satuan pendidikan. Pada dasarnya ada tiga langkah yang perlu ditempuh dalam melaksanakan pengawasan, yaitu (1) menetapkan alat ukur atau standar, (2) mengadakan penilaian atau evaluasi, dan (3) mengadakan tindakan perbaikan atau koreksi dan tindak lanjut. Oleh sebab itu, kegiatan pengawasan itu dimaksudkan untuk mencegah penyimpangan dalam pelaksanaan pekerjaan, menilai proses dan hasil kegiatan dan sekaligus melakukan tindakan perbaikan (Purwanto, 1998:106).

Menurut Onong Uchjana Efendy (1993:131), evaluasi adalah tahap terakhir setelah tahap-tahap penelitian, perencanaan dan penggiatan yang dilaksanakan oleh suatu organisasi. Dalam beberapa hal, evaluasi memiliki karakteristik pengukuran dan penilaian, apakah kuantitaf atau kualitatatif. Evaluasi dalam hal ini diartikan sebagai suatu pengukuran (measurenment) atau penilaian (evaluation) terhadap suatu perencanan yang telah dilakukan oleh organisasi yang biasa dilakukan pada pertengahan, akhir bulan atau tahun. Terdapat suatu perbedaan antara pengukuran dan penilaian dalam suatu obyek dilakukan dalam suatu evaluasi.

Pengukuran (measurement) adalah membandingkan sesuatu dengan satu ukuran, dan pengukuran ini bersifat kuantitatif. Sedangkan penilaian (evaluation) adalah mengambil suatu keputusan terhadap sesuatu dengan ukuran baik buruk, dan penilaian bersifat kualitatif. Mengadakan penilaian meliputi dua langkah tersebut, yaitu mengukur dan menilai, (Suharsimi, 2001: 3). 
Mengingat pentingnya evaluasi dalam suatu organisasi, maka Islam sebagai suatu agama yang komprensip memberikan pedoman-pedoman yang dijadikan sebagai suatu prinsip dalam evaluasi. Sebagaimana disabdakan oleh Nabi Muhammad SAW

$$
\text { حاسبو أنفسكم قبل ان تحاسبو ا, زنو ا أعمالكم قبل ان توزن (الحديث) }
$$

Artinya: Periksalah dirimu sebelum memeriksa orang lain. Lihatlah terlebih dahulu atas kerjamu sebelum melihat atas kerja orang lain.

Hadits tersebut memberikan anjuran kepada setiap pemimpin organisasi maupun para stafnya untuk tidak saling menyalahkan terhadap suatu kelompok atau orang lain, melainkan berusaha untuk berubah ke arah yang lebih baik secara bersama-sama. Evaluasi lebih mengarah pada koreksi dalam pelaksanaan program peningkatan mutu madrasah. Hasil evaluasi sangat penting untuk mengetahui kekurangan-kekurangan yang ada dan kemudian segera merancang kembali dalam rangka menyelesaikan kekurangan-kekurang dan masalah yang muncul. Apabila proses fungsi-fungsi manajemen dilakukan dengan benar dan berdasarkan niali-nilai agama maka upaya peningkatan mutu madarsah akan mudah dicapai.

\section{Konsep Mutu dalam Pendidikan}

Saat ini, mutu menjadi isu yang sangat penting dalam dunia pendidikan. Seperti halnya organisasiyang menfokuskan perhatiannya dalam pelaksanaan efektifitas, efisiensidan pengembangan manajemen serta kinerja organisasi. Banyak berpendapat bahwa perhatian ini memang selalu ada, tetapi sebenarnya hal itu lebih disebabkan karena keadaan seperti kompetisi ekonomi, di mana saat ini kita hidup, menjadikan 'mutu' sebagai pusat perhatian, (Silva, 2007:1). Meskipun demikian apapun alasannya saat ini, mempersiapkan kualitas produk dan jasa layanan merupakan tuntutan yang tidak bisa dihindarkan.

Mutu pada dasarnya diperuntukan bagi organisasi perusahaan, pendekatan mutu ini telah diadopsi untuk usaha non profit seperti organisasi pendidikan. Hal itu penting karena pendidikan harus bisa mengembangkan paradigmanya sendiri tentang bagaimana memanajen mutu karena proses pendidikan itu sendiri memiliki 
kompleksitas yang luar biasa seperti input yang bermacam-macam, interaksi yang ada di dalamnya, dan lulusan yang dihasilkannya yang bervariasi. Setiap madrasah harus mampu memutuskan jalannya sendiri dalam peningkatan dan pengembangannya. Dalam hal ini kedudukan kepala madrasah memiliki peranan yang sangat vital. Meskipun tidak mengapa bila mengatakan bahwa kepemimpinan tidak bisa kita sebut sebagai solusi kekuatan gaib bagi perbaikan madrasah. Tapi yang pasti hal tersebut hanyalah satu diantara berbagai elemen yang ada.

Mutu, menurut Edward Sallis dapat dipandang sebagai sebuah konsep yang absolute sekaligus relative. Mutu dalam percakapan seharihari sebagian besar dipahami sebagai sesuatu yang absolute, misalnya restoran yang mahal dan mobil-mobil yang mewah. Sebagai suatu konsep yang absolut, mutu sama halnya dengan sifat baik, cantik, dan benar; merupakan suatu idealisme yang tidak dapat dikompromikan. Dalam definisi yang absolute, sesuatu yang bermutu merupakan bagian dari standar yang sangat tinggi dan tidak dapat diungguli, (Salis, 2010:51-52). Dengan demikian produk yang bermutu adalah sesuatu yang dibuat secara sempurna dan dengan biaya yang mahal sehingga mutu itu adalah semua yang memiliki kualitas standar tinggi. Mutu dalam pandangan ini digunakan untuk menyampaikan keunggulan status dan posisi.

Sedangkan mutu yang relatif, mutu dipandang sebagai suatu yang melekat pada sebuah produk yang sesuai dengan kebutuhan pelanggannya. Untuk itu dalam definisi relatif ini produk atau layanan akan dianggap bermutu, bukan karena ia mahal dan eksklusif, tetapi ia memiliki nilai misalnya keaslian produk, wajar dan familiar (Salis, 2010:53).

Pandangan ini lebih mirip dengan apa yang disampaikan oleh Juran bahwa mutu adalah kecocokan penggunaan produk (fitness for use) untuk memenuhi kebutuhan dan kepuasan pelanggan, (Nasution, 2001:15). kecocokan penggunaan produk tersebut memiliki dua aspek utama yaitu, produknya memenuhi tuntutan pelanggan dan tidak memiliki kelemahan. Inilah konsep mutu yang tidak terlalu mulukmuluk dan tidak menarget 'mutu tinggi', sehingga dengan demikian memungkinkan setiap orang, baik yang mampu atau tidak mampu 'membeli' mutu tinggi, dapat tetap merasakan pelayanan mutu. 
Secara lebih sederhana konsep mutu kemudian diinterpretasikan oleh ISO 9000 sebagai suatu perpaduan antara sifat-sifat dan karakteristik yang menentukan sampai seberapa jauh keluaran/ mutu barang/lulusan dapat memenuhi kebutuhan pembeli/ pemakai lulusan (Bambang, 2000:41).

Berdasar atas uraian di atas konsep mutu yang dimaksud dalam tulisan ini adalah konsep mutu relatif yang dipaparkan oleh JM. Juran dan Edward Sallis di atas atau konsep mutu yang disampaikan oleh Crosby dan ISO 9000. Artinya dalam proses pengelolaan madrasah, madrasah tidak harus mengeluarkan biaya maupun tenaga ekstra untuk mencapai mutu yang bernilai mahal dan eksklusif, tetapi ia perlu menunjukkan keaslian dan kewajaran sifat-sifatnya serta keefektifannya sesuai dengan tujuan, tuntutan dan kebutuhan masyarakat masa kini dan masa datang.

\section{Manajemen Peningkatan Mutu Madrasah}

Secara umum, manajemen peningkatan mutu adalah gambaran dan karakteristik menyeluruh dari upaya dan proses organisasi untuk menciptakan jasa yang menunjukkan kemampuannya dalam memuaskan kebutuhan yang diharapkan. Untuk itu manajemen peningkatan mutu madrasah meniscayakan semua layanan madrasah agar menfokuskan diri pada tujuan yang telah ditetapkan. Dengan menfokuskan diri terhadap peningkatan mutu tersebut, maka semua kegiatan yang ada dalam proses pendidikan pada madrasah mengarah pada pencapaian tujuan berupa pencapaian visi dan misi dari madrasah itu sendiri.

Dalam konteks pendidikan, pengertian manajemen peningkatan mutu madrasah ini terkait dengan lulusan. Lulusan ini meliputi input, proses, dan output pendidikan, karena sentral layanan pendidikan adalah output secara umum dan lulusan secara khusus, mutu lulusan itu sendiri sangat terkait dengan mutu input, proses dan output. Ketiganya tidak dapat dipisahkan satu dengan yang lain.

Input pendidikan adalah segala sesuatu yang harus tersedia karena dibutuhkan untuk berlangsungnya proses pendidikan. Sesuatu yang dimaksud berupa sumberdaya dan perangkat lunak serta harapan-harapan sebagai pemandu bagi berlangsungnya proses, diantaranya meliputi, 1) siswa: kesiapan dan motivasi belajarnya, 2) 
guru: kemampuan profesional, moral kerjanya (kemampuan personal), dan kerjasamanya (kemampuan sosial). 3) kurikulum: relevansi konten dan operasionalisasi proses pembelajarannya, 4) dan, sarana dan prasarana: kecukupan dan keefektifan dalam mendukung proses pembelajaran, 5) Masyarakat (orang tua, pengguna lulusan, dan perguruan tinggi): partisipasinya dalam pengembangan programprogram pendidikan madrasah.

Mutu komponen-komponen tersebut di atas menjadi fokus perhatian madrasah. Secara lebih rinci dapat disebutkan input sumberdaya meliputi sumberdaya manusia (kepala madrasah, guru termasuk guru BP, karyawan, siswa) dan sumberdaya selebihnya (peralatan, perlengkapan, uang, bahan, dan sebagainya). Input perangkat lunak meliputi struktur organisasi madrasah, peraturan perundang-undangan, deskripsi tugas, rencana, program, dan sebagainya. Input harapan berupa visi, misi, tujuan, dan sasaran yang ingin dicapai oleh sekolah. Kesiapan input sangat diperlukan agar proses dapat berlangsung dengan baik. Oleh karena itu, tinggi rendahnya mutu input data diukur dari tingkat kesiapan input. Makin tinggi tingkat kesiaan input, makin tinggi pula mutu input tersebut, (Depdiknas, 2002:7).

Proses pendidikan merupakan berubahnya sesuatu menjadi sesuatu yanglain. Sesuatu yang berpengaruh terhadap berlangsungnya proses disebut input, sedang sesuatu dari hasil proses disebut output. Dalam pendidikan bersekala mikro (tingkat sekolah), proses yang dimaksud adalah proses pengambilan keputusan, proses pengelolaan kelembagaan, proses pengelolaan program, proses belajar-mengajar, dan proses monitoring dan evaluasi, dengan catatan bahwa proses belajar mengajar memiliki tingkat kepentingan tertinggi dibandingkan dengan proses-proses lainnya.

Output pendidikan adalah merupakan hasil kinerja madrasah. Kinerja madrasah adalah prestasi madrasah yang dihasilkan dari proses/prilaku madrasah. Kinerja madrsah yang dihasilkan dapat diukur dari kualitasnya, efektifitasnya, produktifitasnya, inovasinya, moral kerjanya dan lain sebaginya. Output pendidikan dapat juga dikatakan bermutu jika prestasi madrasah, khususnya prestasi peserta didik dalam berbagai hal akademik maupun non akademik menunjukkan pencapaian yang tinggi. 


\section{Kesimpulan}

Dalam upaya peningkatan mutu madrasah yang sangat berperan dalam menjalankan tugas adalah kepala madrasah. Tugas kepala madrasah yaitu menjalankan fungsi fungsi manajemen sesuai dengan visi,misi dan tujuan madrasah. Fungsi fungsi tersebut yaitu merencanakan, mengorganisasikan, mengarahkan, mengkoordinasikan, mengawasi dan mengevaluasi seluruh kegiatan madrasah, yang meliputi bidang proses belajar mengajar, peningkatan dan pengembangan kinerja guru, administrasi kantor, administrasi siswa, administrasi pegawai, administrasi perlengkapan, administrasi keuangan, administrasi perpustakaan, dan administrasi hubungan masyarakat.

Implementasi manajemen peningkatan mutu madrasah juga meniscayakan semua pelaksanaan layanan madrasah agar menfokuskan diri pada tujuan yang telah ditetapkan. Dengan menfokuskan diri terhadap peningkatan mutu tersebut, maka semua kegiatan yang ada dalam proses pendidikan pada madrasah mengarah pada pencapaian tujuan berupa pencapaian visi dan misi dari madrasah itu sendiri.

Menfokuskan diri pada semua yang telah di tetapkan oleh madrasah berupa visi, misi dan tujuan akan menjadikan layanan pendidikan di madrasah memberikan arah yang jelas dan berdapak pada munculnya kepuasan pada seluruh pelanggan baik intenal maupun ekternal. Pelayanan yang baik pada pelanggan akan menjadikan madrasah selalu diminati oleh masyarakat dan akan tetap menjadi eksis sampai kapanpun. Sehingga kesan madrasah sebagai sekolah yang termarginalkan akan hilang dan berganti menjadi sekolah yang sesuai dengan harapan pelanggan.

\section{Daftar Pustaka}

Ahmad Hatta, Tafsir Al-Qur`an Perkata Dilengkapi Dengan Asbabun Nuzul \& Terjemah, (Jakarta: Maghfirah Pustaka, 2009).

Bambang H. Hadiwiarjo, \& Sulistijarningsih Wibisono, Memasuki Pasar Internasional Dengan ISO 9000. (Jakarta: Ghalia Indonesia, 2000).

Burhanuddin, Analisis Administrasi, Manajemen dan Kepemimpinan Pendidikan (Jakarta: Bumi Aksara, 1994). 
Nurul Yaqien - ImplemEntasi Manajemen Peningkatan Mutu ...

Departemen Pendidikan Nasional. Manajemen Peningkatan Mutu Berbasis Sekolah. (Jakarta: 2002).

Edward Sallis,. Total Quality Management in Education. Alih Bahasa oleh Ahmad Ali Riyadi dan Fahrurrozi. (Jogjakarta: IRCISoD, 2010).

Fridreck Taylor W, Scientific Management, (New York: Happer and Breos, 1974).

Hadari Nawawi,. Administrasi Pendidikan, (Jakarta: PT Gunung Agung, 1983).

Hendyat Sutopo, Manajemenen Pendidikan, (Malang: Program Pascasarjan Universitas Negeri Malang, 2001).

Imam Abi Abdillah Muhammad Bin Ismail Bin Ibrohim Bin Mughiroh Bardizah Al-Bukhori Al-Ja'fi, Shahih Bukhori, Juz 1, (Beriutlibanon; Dar-al kutb al Ilmiah, 1992).

Jawahir Tanthowi, Unsur-unsur Manajemen Menurut Ajaran AlQur'an, (Jakarta: Pustaka al-Husna, 1983).

Malayu S. P. Hasibuan, Manajemen Sumber Daya Manusia, (Jakarta: Bumi Aksara, 2012).

Malayu SP. Hasibuan, Manajemen: Dasar, Pengertian, dan Masalah (Jakarta: Bumi Aksara, 2001).

M N. Nasution. Manajemen Mutu Terpadu (Total Quality Management). (Jakarta: Ghalia Indonesia, 2001).

Mochtar Effendy, Manajemen : Suatu Pendekatan Berdasarkan Ajaran Islam, (Jakart: PT. Bhatara Karya Aksa, 1986)

Mulyono, Manajemen Administrasi dan Organisasi Pendidikan. (Jogjakarta: Ar Ruzz Media, 2008).

Nunung Chomzanah dan Atingtedjasutisna, Dasar-Dasar Manajemen (Bandung: Penerbit Armico, 1994).

Nanang Fattah, Landasan Manajemen Pendidikan, (Bandung: Remaja Rosdakarya, 2009).

Ngalim Purwanto, Administrasi dan Supervisi Pendidikan. (Bandung: PT. Remaja Rosdakarya, 1998).

Onong Uchjana Efendy, Human Relation dan Public Relation, (Bandung: Mandar Maju, 1993). 
Richard L. Daft. Manajemen, terj. Edward Tanujaya, (Jakarta: Salemba Empat, 2008).

Stephen R. Robbins, Perilaku Organisas Jilid I, Terjemahan Tim Indeks, (Jakarta: PT. Indeks Kelompok Gramedia, 2003).

Soewadji Lazaruth, Kepala Sekolah dan Tanggung Jawabnya. (Yogyakarta: Kanisius, 1994).

Suharsimi Arikunto, Dasar-dasar Evaluasi Pendidikan, (Jakarta: Bumi Aksara, 2001).

Silva Roncelli-Voupot, 2007. Leading For Quality. National Leadership School, Ljubljana Slovenia. Bahan Review Mata Kuliah Manajemen Mutu. Pascasarjana UIN Malang.

Soetopo, Hendiyat, Manajemenen Pendidikan. Malang: Program Pascasarjan Universitas Negeri Malang, 2001

Tim Dosen Administrasi Pendidikan Univ. Pend. Indo., Manajemen Pendidikan, (Bandung: Alfabeta, 2011).

Usman, Husaini. Manajemen: Teori, Praktik, Dan Riset Pendidikan. Jakarta: PT Bumi Aksara, 2010.

Ulbert Silahahi, Studi tentang Ilmu Administrasi: Konsep, Teori, dan Dimensi, (Bandung: Sinar Baru Algensindo, 2002) 
